\title{
MEMOIRS
}

\section{ALGERNON CHARLES BRADBURY}

ON 6 September 1964 there passed away at the age of 79 one of the most respected members of the actuarial profession in Melbourne, in the person of the late Algernon Charles Bradbury.

He was born in England but spent his early childhood in New Zealand, his father being a Congregational Minister. In his boyhood he came to Australia where he was educated at Wesley College, Melbourne, and joined the staff of the Australian Mutual Provident Society in January 1902. While there he began his career by studying for the examinations of the Institute of Acturaries (London) when the facilities for study were far different to those operating today. In 1920 he transferred to the staff of the Australian Temperance and General Mutual Life Assurance Society Limited, occupying the position of Assistant Actuary. In 1947 he was appointed Joint Actuary, which rank he held until his retirement in December 1954.

Soon after the establishment of the Victorian branch of the Actuarial Society of Australasia in 1922 he was elected Hon. Secretary of the branch and proved a most efficient and enthusiastic Secretary, holding the office until 1934. In 1935 he was elected Vice-President and, the following year, President of the Society and thereafter served as a member of the Branch Committee and as Hon. Auditor.

Possibly remembering his own difficulties in completing his course of studies for the examinations, he was always interested in the welfare of students, helping them in every way he could. He acted as the Representative of the Actuarial Tuition Service from 1947 to 1954 and during the same years was Supervisor for the Institute Examinations in Melbourne.

He was never happier than when working on some involved calculation or conducting an investigation of some kind, particularly in connexion with superannuation or pension funds. He acted as actuarial adviser to several Tasmanian Government or semi-Government superannuation funds until they were finally handed over to the Commonwealth Actuary for periodic valuation.

As a man he was very quict and reserved but he had a very strong sense of what was right and what was wrong and never hesitated to express his opinions, particularly when he felt some injustice was being done. He was a bachelor and his main interests were his actuarial work and his work for his Church. After his retirement he devoted a lot of his leisure to this Church, the Victorian Branch of the Congregational Union, where in addition to being a member of the Finance Committee he handled all the work and control of the Church's Superannuation Fund.

He was much respected and liked by all with whom he came in contact and he will undoubtedly be much missed.

H. M. JACKSON

\section{HAROLD EDWARD WILLIAM LUTT}

Harold Edward William Lutt died at the age of 87, on 22 September 1964. He started his business life with the Commercial Union Assurance Company Limited in 1894, when he started studying for his actuarial examinations. After serving with that Company for seven years, he became Accountant of the Mutual Life Association of Australia, and then in 1903 he entered the service of the Northern Assurance Company Limited as Chief Clerk in the Life Department. 
During the First World War he served as an Assistant Paymaster, R.N.R., and saw active service in the South Atlantic and Pacific Oceans, including the Battle of the Falkland Islands and the Dardanelles, and was afterwards appointed Secretary to the Divisional Commander of Air Stations at the Nore.

After the war he returned to the Northern to take up the appointment of Secretary to the London Board, a position which he held until 1929, when he become Actuary and Life Manager of the Company until his retirement in 1941.

Harold Lutt qualified as a Fellow of the Institute of Actuaries in 1899. In that year he shared the second Chisholm Prize with J. M. Allen for an essay on 'Discounted Bonuses' and subsequently he read a paper to the Institute on 'Extra Premiums' which, for many years, formed part of the reading for the examinations. He served on the Council from 1919-22 and took part in the Institute's discussions on a number of occasions.

He was a man of great ability and all those who worked with him had the greatest possible respect for him. To those who worked under him, he was always very kindly and gave every encouragement to them in their work and studies.

T. W. HAYNES

\section{WALLACE WHITE WILLIAMSON}

WALlace White Williamson died on 22 September 1964 at the age of 76. Born in Norwich and educated at the King Edward VI School, 'W. W. W.', as he was affectionately known to many, joined the staff of the Norwich Union Life Insurance Society in 1904. He qualified as a Fellow of the Institute in 1915 and, after a short period of war service with the Inns of Court O.T.C., was appointed Assistant Actuary in 1919.

In 1934 he became Secretary and Joint Actuary, and in 1938 General Manager and Actuary. At that time, his brother, the late E. F. Williamson, was General Manager of the Norwich Union Fire Society, a post W. W. Williamson was also to fill from 1947. On his retirement from the general managerships of both companies in 1952 he was appointed to a seat on the Boards, from which he retired on attainment of the age limit in 1963. In recognition of his services he was then appointed Honorary Consultant Actuary.

Williamson's main service to the Institute was as a member of Council from 1932-36 and from 1938-42. In addition he organized, for some years after the First World War, tuition for the Institute's examinations for Norwich students. By these efforts, and by the assistance he obtained from E. F. Spurgeon in visits to assist tuition, Williamson was instrumental in establishing a nucleus of Institute membership in Norwich.

The regard in which his professional colleagues held him was shown by his election to membership of the Gallio Club in 1932, and of the Actuaries' Club in 1935. He was also a founder member of the Fellowship Club.

To all who worked with him in his business career he was both colleague and friend. Those of us who were close to him knew him as a leader of the highest moral principles who inspired respect, affection and enthusiasm in his team-for he was always a 'team' man, ever ready to give credit to the efforts of others. To a strong character, sound judgment and a decisive mind, he added a breadth of knowledge which ranged far beyond the field of insurance; an ability to cast aside detail and grasp essentials; a happy knack of bringing the best out of his colleagues by implicit trust in them; and an inherent courtesy and charm which endeared him to all who came in contact with him. Above all he had a puckish sense of humour which carried him and us through many problems, and helped him to face his last illness with wonderful courage. 